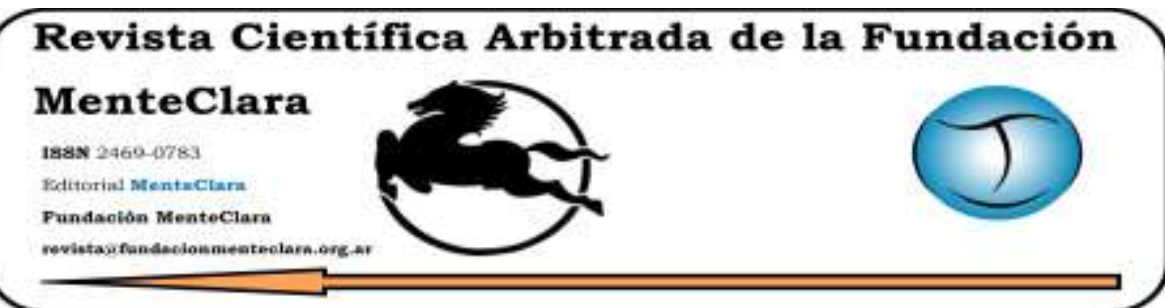

Artículos atravesados por (o cuestionando) la idea del sujeto -y su género- como una construcción psicobiológica de la cultura. Articles driven by (or questioning) the idea of the subject -and their gender- as a cultural psychobiological construction

Vol. 5 (2020), enero-diciembre

ISSN 2469-0783

https: / / datahub.io/ dataset/2020-5-e142

\title{
THE GREAT PERFECTION OF BEING A HUMAN BEING: THE DIRECT KNOWING OF BEING AND THE METABOLIZATION OF EXPERIENCE
}

\author{
LA GRAN PERFECCIÓN DE SER UN SER HUMANO: EL CONOCIMIENTO DIRECTO \\ DEL SER Y LA METABOLIZACIÓN DE LA EXPERIENCIA
}

Rudolph Bauer rbauer@rsbauer.net

Center for Consciousness Studies and Washington Center for Phenomenological and Existential Psychotherapy Studies. United States of America

Cómo citar este artículo / Citation: Bauer R. (2020). "The Great Perfection of Being a Human Being: The Direct Knowing of Being and the Metabolization of Experience". Revista Científica Arbitrada de la Fundación MenteClara, Vol. 5 (142).

DOI: https://doi.org/10.32351/rca.v5.142

Copyright: () 2020 RCAFMC. Este artículo de acceso abierto es distribuido bajo los términos de la licencia Creative Commons Attribution 4.0 International License (CC BY 4.0). Recibido: 25/02/2020. Aceptado: 04/03/2020 Publicación online: 06/03/2020

Conflicto de intereses: None to declare.

\begin{abstract}
In this paper we have phenomenologically explored the profoundly human experience of awakening to Being. We have explicitly explored the phenomenology of Direct Perception of Being and we have phenomenologically elaborated the Metabolization of Experience and the Power of the Transmission of the Field of Awareness which is the Field of Being. We have also elaborated the Traces of Metabolized Experience that are the energetic radiant field of luminous Being that continues life after life and death after death.
\end{abstract}

\section{Resumen}

En este artículo hemos explorado fenomenológicamente la experiencia profundamente humana del despertar al Ser. Hemos explorado explícitamente la fenomenología de la percepción directa del ser y hemos elaborado 
fenomenológicamente la metabolización de la experiencia y el poder de la transmisión del campo de la conciencia, que es el campo del ser. También hemos elaborado las huellas de la experiencia metabolizada que son el campo radiante energético del ser luminoso que continúa vida tras vida y muerte tras muerte.

Keyw ords: tantra; experience; field of Being; awareness

Palabras Claves: tantra; experiencia; campo del ser; consciencia 


\section{Introduction}

Rongzom Zangpo, the brilliant Dzogchen Master of the 11th century CE Tibet taught that All Human Beings are the profound field of awakening. In the language of phenomenology, this means that all Human Beings are the profound field of Being. All Human beings are manifestations of the field of Being as the field of Being in singular expression. I am and you are, a manifestation of the field of Being as the field of Being in our own form of singularity.

In this phenomenology of immanence, the manifestation and the manifesting are ontologically of the same Being. The Great Dzogchen invocation declares "May I realize that all phenomena are the Dharmakaya." This invocation in phenomenological language means "May I realize that all phenomena are the self- manifestation of Pure Being. All Phenomena are Pure Being". This is an explicit declaration of philosophical immanence (Rongzom, 1017).

\section{The Meaning of Awakening}

Rongzom Zangpo taught that Awakening means our direct knowing of Being. Awakening is our non-conceptual experiencing of the ontological openness of our awareness. Awakening means our direct knowing of our non-conceptual experience of the radiant illumination of the Being of our awareness. And our Awakening, furthermore means our direct nonconceptual knowing experience of the continuous unfolding of the "Presence of Being." Awakening is our direct knowing experience of Being and is not a mere belief about Being or a thought about Being.

As Cardinal John Henry Newman describes in his great text 'An Essay on The Grammar of Ascent,' belief is an intellectual ascent to ideation. 
Belief is a function of our mind. Belief is an intellectual experience (Newman, 1903).

Awakening is a direct non conceptual experiential knowing of Being, an unthought known to be thought in time. Thought itself is not the mental ideation about a belief. True thought reflects the direct experiential knowing of the Being of Phenomena and our direct experiential knowing of the Phenomena of Being. Our direct knowing of the Being of phenomena reflects the union and integration of our mind within our field of our Being. Ideation is mind alone knowing. Thought is the knowing that reflects union of our mind knowing phenomena and our awareness knowing the Being of the phenomena.

\section{Direct Knowing of Being}

Awakening is the opening of our Being's perception of Being. Awakening is the experiential opening of our direct knowingness of Being. Our Awareness knows Being and the Being of beings. Awakening is the awakening of our awareness of the field of Being within us, and the field of Being pervading us, and surrounding us. Our deepest and truest awakening is the unfolding experiencing that we are the field of Being which is infinite in its horizons, vast and multidimensional.

In becoming aware of our own innate innermost field of awareness, we experience Being that is manifesting within us and around us. Being is always manifesting beings. Being is always manifesting the Being of beings. True awakening is simply the lively experiencing of field of Being which is always present in its manifestation and manifesting. The manifestation and manifesting of Being as beings, is both experiential and ontological oneness. This oneness is the sameness of Being in all the beings and as all beings. This is the experience of Una Voce that Dun 
Scotus, Spinosa, Deleuze, Meister Eckhart and so many others have elaborated through time. All beings are the One sameness of Being (Bauer, 2020).

In the Dzogchen Tibetan tradition Dudjom Lingpa elaborated that there is the same oneness and same Purity of the Being in all human beings. As the Dakini said to Dudjom Lingpa "You and I are indivisible" (Lingpa, 2015). In Dudjom Lingpa's Dzogchen tradition, self-liberation is the experience of Equality Consciousness. In the Kashmir Shavism of Swami Muktananda, self- liberation is the experience of Equality Consciousness. Both Dzogchen and Kashmir Shavism reflect Philosophical Immanence and the liberating state of Equal Vision. Equal Vision is seeing the Purity of the Being in All Human Beings whatever their personal psychological characteristics.

All human Beings are fields of awakening, fields of knowing. Knowing the field of Being is essential to humanness. Humanness is our foundational opening to Being. Knowing the field of Being is the greatest of human knowingness. Knowing the field of Being in our self and in other human Beings sustains equality consciousness, sustains humanness. This knowing is non conceptual and is a direct pre-reflective knowing. This is the natural way of seeing what is.

Knowing the field of Being as human beings is natural mysticism. Human Being-ness is awakened, and human beings are the field of Being. They are the field of Being's direct knowingness. Our Direct open knowing is our own Being knowing the field of Being. Our mind knows form and our awareness knows Being. Awareness is our Being knowing Being. Our Mind is ontic and our awareness is ontological. Human beings are ontic ontological beings. Our sense of self is an ontic ontological sense of self. Our sense of self is our sense of embodied Beingness (Bauer, 2019). 
Humans beings are the field of Being. They are a field of gnosis. Gnosis or Jnana implies and means the direct knowing of Being. Our gnosis or jnana is our direct knowingness knowing of Being. Our Being knowing of Being is gnosis. This is profound knowing because Being is not easily understood by our mind. The experience of Being is difficult to conceptualized and difficult to language. The experience of Being is difficult to think or experientially language. Our mind does not directly experientially know Being. Our mind can think about Being. Our mind thinks about Being as a form of metaphysics. In metaphysics, Being is an idea. Thinking about Being is not knowing Being directly. If you are in mind alone and absent of awareness you will experience Being-less-ness. Being-less-ness is profound suffering. Being-less-ness is life empty of Being. Experiencing Being-less-ness in the 6th century BC, Gautama declared "All life is suffering."

\section{Gnosis We Are!}

You and I do not have gnosis but actually we are gnosis. Babies do not have gnosis they are gnosis. Babies are the direct knowing of Being through the embodiment of the Being of their mothering. In time our developing mind can cloak gnosis, contain gnosis, obscure gnosis. Our developing mind can contextualize and hide gnosis. Our mind even denies gnosis. The contemporary science of mind obscures direct knowing of Being. Or worst, our mind conceives of our direct knowing as "super natural" or only for the saintly and holy (Daws, 2016).

Human beings are Gnosis, human beings are jnana. Most often, human beings do not know they are direct knowingness of Being. Human beings often think they only know form. Human beings think they are only their mind. They think Being is only philosophical ideation, and they 
do not the experience the actuality of Being which manifests them, and is manifesting the world within which they live. The rationalistic mind devalues direct knowing. The person who is located only in their rationalistic mind, dissociates themselves from the primordial field of direct knowing. This is the most basic dissociation of human beings, the dissociation of their mind from their immediate direct awareness of Being. This is the loss of their ground of Being-ness. Their sense of self becomes their mind alone.

\section{Ontic-Ontological Being}

Phenomenological philosophers such as Merleau-Ponty and Martin Heidegger and existential psychoanalysts such as Rollo May, Donald Winnicott, Menard Boss, Michael Eigen, and Henry Elkin experientially describe that we are ontic ontological Beings. We are ontic as mind and body, and we are ontological as Being as embodied Being. Our sense of self is our sense of our embodied Being (Trigg, 2016).

Rongzom Zangpo describes how all the places of our experience, all the locations of our experience are the spaces of our experience and within these spaces of experience, the naturally manifestation of self-appearing gnosis takes place. Self-appearing gnosis is the direct perception of Being and the perception of the Being of Phenomenological forms. Our experience contains the sixth senses. The senses are perceptual fields of human beings within the field of primordial awareness, primordial knowingness.

The field of awareness is the field of direct knowing, the field of Gnosis. Gnosis or Jnana or Direct Perception is the naturally occurring field of direct knowing which contain and holds the human's sense fields, and the sense fields of the embodied mind and body. The field of direct 
knowing moves directly into Being. The field of direct knowing also moves directly through the instruments and senses of the mind into the blended knowing of the Being of embodied forms, and the phenomenological forms of embodied Being.

There is a natural union between the embodied field of Being and the embodied mind knowing embodied forms of Being. This is the ontic ontological union of the Being of a human being. This simultaneous union of mind and awareness allows the One knower to know the forms of Being and the Being of the forms. This union allows the One Knower to live their life in the Sea of Being through the Being of human forms, the Being of animate forms and the Being of inanimate forms.

\section{Intertwined Union of Mind and Awareness Field}

This intertwined union of mind and awareness allows the One Knower to know the Non-Duality of Being within the Duality of beings, and to know the Duality of beings within the Non-Duality of Being. This is the natural path of self-liberation. The experience of the Non-Duality of Being within the Duality of beings and the Duality of beings within the NonDuality of Being is the path of Immanence. This is not the path of Transcendence. This is the self-liberating experience of oneness within difference and difference within oneness. As the Dakini said to Dudjom Lingpa "You and I are indivisible".

Our field of awareness both supports and can permeate the field of our embodied mind. Gnosis can be without mind, and gnosis can be with mind. Our mind can be within Gnosis. Mind can also be alone and dissociated from the base of Gnosis, the base of Awareness, the Base of Being. The most primary dissociation of a human being is the dissociation 
of their mind from the innate field of primordial awareness. This is a dissociation of mind and functions of the mind from the field of Being.

Mind in union with Gnosis is the power of knowing the forms of Being and the Being of forms simultaneously. This intertwined union of mind and awareness brings forth the liberating experience of Duality of beings within the Non- Duality of Being. And within the Non-duality of Being we experience simultaneously the Duality of beings.

\section{Being-less-ness}

Phenomenologically, we can become absent of the sense of Being, we can become Being-less. Being-less-ness is an unbearable source of human suffering. Becoming Being-less is experiencing the empty voidness of the Non-Being of the life of forms without the base of Being. The experience of the Being-less-ness of phenomenological form is the unbearableness of falling into the abyss of absence. Without the experience of the Being of human beings, Equality Consciousness disappears and Equal Vision disappears (Capobianco, 2014).

We can become directly aware of the field of Being by becoming directly aware of our field of awareness. Our awareness is our field of Being knowing Being. Our awareness is Being's knowingness as us, and through us. Mind alone does not know Being, does not experience the field of Being, does not experience the fullness of Being. Mind alone is empty of Being. Mind alone is suffering.

We can become aware of Being as this field of Being, and we can be living in natural sea of Being of all the human beings. There is an unfolding existential developmental progression of our embodying the field of Being. In the beginning, we can experientially hold the field of Being within us. We hold the field of awareness within us. Then we can 
move further and be in the field of Being and the field of Being surrounds us and permeates us. We are not only holding the field of awareness, we are in the field of awareness. The field of awareness surrounds us. The field of Being is infinite in its horizons, vast, and multidimensional. Nonetheless, we can still move even deeper and further and we become the field of Being. We become what we are. We are the field of Being. We are the innate field of primordial awareness. We become the great expanse.

\section{Ongoing Continuity of Being}

The power and actuality of the field of Being becomes our own ongoing continuity of the experience of Being. This ongoing continuity of Being continues throughout life, and naturally continues life after life and death after death. Our own Being within the Sea of Being is described in Dzogchen as Being unborn and undying. Being is our formless awareness. Our experience of formless awareness is the nature of our experience of Being.

\section{A Phenomenological Meditation}

In the phenomenological meditation of Becoming aware of awareness and in becoming aware of awareness, we come to know the Being-ness of our own Being. And through the cumulative use of this phenomenological meditation we more deeply and completely embody the Being-ness of our Being. This form of Phenomenological Meditation is a process of the experiential unfolding of the embodiment of awareness that is our becoming embodied Being. Our Meditative absorption of awareness, -by becoming aware of awareness- is naturally occurring gnosis, is the naturally occurring direct knowing of Being. This direct knowing of 
awareness is our direct Knowing Being within our own being and knowing Being within the Being of other beings. This Gnosis, this Jnana is selfliberation. Dzogchen invokes and calls the direct knowing of Being as Rigpa. Not knowing Being is Ma Rigpa. Many people do not know the Being of phenomena and they suffer the absence of Being. They suffer the absence of experiencing the Being of phenomena, including their own sense of innermost Beingness (Longchen, 2001).

The first step of this phenomenological meditation is to pause or suspend our mind. Then within this brief pause and suspension of mind, we turn our awareness from being focused on our mind and the functions of our mind. We are going beyond mindfulness and so we turn our focus of our awareness on to awareness itself. In becoming aware of our own awareness, we become aware of Being. Awareness is Being's knowingness. Awareness is Being's knowingness of Being. Heidegger called a human being openness to Being "Da Sein".

After establishing our self in awareness of awareness, and in our direct knowing of Being, we then integrate our mind and the functions of our mind into this field of awareness, into this field of Being. Then as the One Knower whose mind knows the form of phenomena, and whose awareness knows Being, then we as the One knower -whose mind and awareness are now integrated-, can know the Being of phenomena and the phenomena of Being. We can know naturally the Non- Duality of Being within the Duality of beings and we can know the Duality of beings within the Non- Duality of Being. This is the path of natural selfliberation. 


\section{Multidimensional Being}

Our experience of our Being is multidimensional, as Being is multidimensional and infinite in its horizons. Our experience of our ordinary life world is Being in its self-manifestation of and as the ordinary life world. Dzogchen calls this ordinary reality dimension of Being's selfmanifestation Nirmanakaya.

Then our experience of the ordinary life world, unfolds and opens into the subtle existential dimension of our luminous experience which is cosmological and archetypal. This is the dimension of luminous contextual intensity. Within this dimension there are spheres of archetypal energies and archetypal luminosity. This dimension of primal and primordial energies can be integrated into our ordinary life world. Dzogchen calls this archetypal dimension Sambhogakaya.

Then there is the foundational dimension of the source or ground of Being. Dzogchen calls this dimension the Dharmakaya. The Dharmakaya is naturally occurring Pure Being. Dharmakaya is Pure Being which is the source of the field of Being, but Dharmakaya is not a being. Being is not a being. Being, which is not a being, is the source of infinite beings. Being manifest beings by self-manifesting Being existing within beings as Being. The Dharmakaya is the power of self-manifestation. The Dharmakaya is the cosmological power of compassion.

\section{Luminous Nature}

Ordinary conscious awareness is luminous by nature. Naturally arising gnosis is the nature of Being. Naturally arising gnosis or jnana is the direct knowing of Being. You can know gnosis and yet not be able to language gnosis. You can know gnosis and yet not think or conceptualize gnosis. Knowing gnosis is a non-conceptual knowing, an unthought 
known. Gnosis is our direct knowing of Being within us and within the world of phenomena.

Rongzom describes how all phenomena are seen to be manifestations of Being within the single vast sphere of Bodhicitta. Bodhicitta is the nature of awareness, as compassion, and compassion is the primordial self-manifestation of luminous Being-ness within our self and others. Bodhicitta is the experience of awareness within our self and others as Pure Being, as the manifestation of Pure Being.

\section{Transmission and Manifestation}

In our manifestation of Bodhicitta we have the power to transmit and manifest our experiencing of luminous Being into other human beings. We can transmit and manifest compassion into the world, we can transmit Pure Being into the world. We can transmit the Pure field of Being into the past of a person, we can manifest the Pure field of Being into the present moment of a person and we can transmit Pure field of Being into the future time of a person.

This power of Compassion is ultimately Timeless awareness. Compassion is Timeless awareness in time. Compassion is our capacity to be in timeless awareness and in time simultaneously. Timeless awareness is the fourth time. Timeless awareness is the power of manifestation. Timeless awareness is the essence of the phenomenology of awareness. Timeless awareness is the essence of Dzogchen. Timeless awareness is the essence of Kashmir Shavism. Timeless awareness is the essence of existential phenomenology.

Bodhicitta signifies the indivisibility of the power of our awareness and our self-manifestation of Being. Awareness is the Knowing of Being and the Knowingness of our Being is awareness. There is the knowing of mind 
which is the knowing of phenomenological form and there is the direct knowing of awareness which is the knowing of formless Being. Being knows Being. Awareness is the knowingness of Being knowing Being. Primordial Awareness is the power of manifestation.

\section{Luminous Energy}

The awakening of awareness is an awakening of the energy of Being, the 'phusis' of Being. Phusis is a Greek word meaning emergent Being. Phusis is the infused embodiment of the light of Being as unfolding luminous vital energy. This is the energy of becoming. Being is luminous energy. This is the energy of self-manifestation. In the mystical non-dual tradition of Kashmir Shavism, this 'phusis' or the unfolding of luminous vital energy is Shakti. As Bodhidharma of the 6th century CE the great Dzogchen Master of Transmission said "Beyond words and letters there is a transmission, this transmission does not belong to any tradition. This transmission is the nature of human awareness". He also added that this transmission is the Buddha. Buddha is not a person but our natural transmission of awareness as Being. Our capacity of natural transmission is the natural self-manifestation of the luminous vital energy of Being into other human beings.

All human Beings are seen as the profound pure field of awakening and profound pure field of manifestation. Sensient beings are awakened and they are the field of Being. They are the awakened field just as they are, and they are the source of all the qualities that arise as the Great Perfection. This is profound knowing because this knowing is often hidden by the forms of phenomena. The very forms of manifested phenomena can obscure the self-manifestation of the field of Being. Gazing and cutting through phenomena and the opening up of 
phenomena as the embodiment of light are an essential human praxis. This seeing into the Being of phenomena -the Light of phenomena- is a praxis of natural self-liberation. This is the profundity of our ordinary human existence. This is the power of seeing through, this is the power of gnosis, the power of direct perception.

This power of transmission of awareness is not the power of Patriarchal Culture or Patriarchal Institution as some souls are taught to think. The power of transmission is completely personal and not a function of Patriarchal Institutionalization or Patriarchal authority. Patriarchal Institutionalization pretends ownership and pretends the transmission of Being as Brand of religious transmission. There is a religious defining specialty which is to pretend ownership of human transmission.

All domains of our experience are seen as naturally occurring selfappearing gnosis. We live in events of gnosis and in events of direct knowing. All phenomena are seen as the manifestations of Being. All domains or places of experience are naturally occurring gnosis appearing to itself. These places of experience comprise the sentient being's field of sense experience. Naturally occurring gnosis exists in the fields of human experience. Gnosis is naturally occurring within and through the fields of human sense. The Dharmakaya remains just as it is, the nonconceptual naturally arising Direct knowing of Being. Gnosis manifests in all humans but can be obscured by mentalistic mind. Patriarchal traditions pretend that they are the ownership of Being and the awareness of Being and the transmission of Being. All Religious Patriarchal Traditions pretend this ownership of the transmission of Being (Bauer, 2020b). 


\section{Esoteric Knowing of Being}

Archetypal realms of Being are gnosis and they are unfolding archetypal spheres of self-arising gnosis. The archetypal Dakini is the archetypal symbolic dimension of Direct Knowing of Being. The archetypal symbolic Dakini's are innate spheres of luminous knowingness and luminous Being-ness that are primal dimensions of ontological Being. The Dakini is an archetypal dimension of our own nature of Being.

\section{Bliss Over Comes Suffering}

Bliss is the nature of our experience of Pure Being and the Bliss of Pure Being is our Pure non conceptual knowing of Being. Bliss emerges within the Pure gnosis of our direct knowing of the Being of beings. The tantras declare that the Bliss of Being over comes suffering. Amrita is the manifestation of embodied Bliss. Amrita is the soma of bliss. Amrita is luminous viscous liquidity of embodied Being as Bliss. Amrita is Nectarian pervasive viscous light of embodied Being.

Within the power of our own embodied awareness, is incomparable gnosis, and within gnosis is the opening of the saturation of spontaneous Bliss. The esoteric experience of liquid viscous luminous Bliss reflects the elemental energies of Being. There is the Bliss of the fire element, the Bliss of water element, the Bliss of wind element, the Bliss of the earth element, the Bliss of air element and the Bliss of spaciousness. Each of these subtle elements have a felt sense of Beingness. In experiencing the field of Being, the embodied felt sense of these subtle elemental energies can be experienced as they self-manifest within our luminous embodiment of Being. 


\section{The Metabolization of Experience}

Awareness metabolizes experience. Abinavagupta the 9th century $\mathrm{CE}$, Master of Kashmir Shavism would write that awareness is like a powerful digestion. This understanding that awareness metabolizes experience is most important and a most fundamental understanding of the power of our innate field of awareness (Baumer, 2011).

The awareness field of embodied Being metabolizes and transmutes experience. Through this metabolization of experience luminous vital energy becomes available for spontaneous knowing action. Awareness metabolizes our experience, our multidimensional experience. Our mind has only a minimal power for metabolization of experience compared to the power of our fully embodied awareness field which is embodied Being.

The awareness field of embodied Being metabolizes and transmutes experience. The awareness field of Being metabolizes painful and fixated states of experience. The awareness field metabolizes saturated states of affect, saturated states of thought, saturated states of sensation and saturated states of memory. The awareness field of embodied Being metabolizes dissociated states of fantasy and dissociated states of affect that can be re-integrated and assimilated into the field of transitional awareness, the field of primordial knowingness.

The Existential experiential psychotherapies place great emphasis on the metabolization of experience through the power of awareness. Erving and Miriam Polster of the Gestalt Psychotherapy Tradition emphasized metabolization of experience as focal in psychotherapy. Fritz Perl's text Ego, Hunger and Aggression is an elaboration of the understanding that Gestalt approach to the metabolization of experience is foundational and the essence of gestalt psychotherapy (Bauer, 1976). 
The metabolized experience is transmuted and the metabolized experience becomes the embodied field of lucid and luminous Being. Existential psychoanalysis such as Winnicott, Masud Khan, Austin Deslaurier, Michael Eigen, Henry Elkin, also emphasize the power of the metabolization of experience in order to have authentic experience of embodied self -Being- to unfold and to be sustained through time (Winnicott, 1971).

The awareness field metabolizes bliss and metabolizes love, and metabolizes happiness, and metabolizes erotic experience. The mind does not have the same power to metabolize traumatic experience as does the embodied field of awareness. The mind understands the context of experience, the mind understands the signification of experience, the mind understands the sensation of experience and the mind understands the historical manifestation of experience. Yet the mind does not directly or fully metabolize experience. The mind does not directly digest the experience and does not transform the experience into energy, vitality and light. The mind's metabolization of saturated experience is limited and mind cannot alone liberate us. Our mind contextualizes experience and the meaning of experience. The mind often lives in bewilderment.

\section{The Metabolization Process and The Traces of Experience}

The metabolization process of the embodied awareness field is much more powerful than our minds capacity to metabolize experience and to metabolize the experience of events and circumstance. Our embodied field of awareness metabolizes the experience of thoughts, sensations, memory, fantasy and the immediate experience of circumstances and events. This metabolization of experience is a source of self -liberation. 
All metabolized experience becomes the experiential field of Being. This is an important understanding and yet not easy to understand. All metabolized experience becomes the experiential field of Being. In the metabolization of experience, all experience becomes integrated within the field of Being as the field of Being. All experience becomes assimilated into the field of awareness which is the field of Being. The "form" of the phenomenological experience is metabolized and dissolved and what remains of the Being of the phenomenological form is traces of the field of Being, and traces within the field of embodied Being.

The Mind's Memory of the experience becomes the experience of a trace within the field of awareness. Memory of our mind is metabolized and our mind no longer holds the living actuality of the experience. The living actuality of experience is metabolized within the power of awareness and becomes a trace with the field of embodied Being.

The trace of the experience is not simply a cognitive memory, but a trace is the meaningful configuration of radiant subtle energy of the experience within embodied Being. The trace is not a psychological memory as such, but the trace reflects the subtle experience of the radiance of the field of our embodied Being's experience of the event. Merleau Ponty explored the nature of phenomenological trace within the field of awareness as the field of the embodied Being. The trace is not a psychological memory but a configuration of radiance within the field of Being. Traces are the resonance of the field of our Being to the experience of the unfolding event. Traces are subtle configurations of the radiant energy of the field of Being. In Dzogchen language, these tiny spheres of radiance are called Thigles.

The field of Being metabolizes the phenomenological form and densifies the phenomenological form and transmutes the phenomenological form 
into a trace within the field of Being as the field of Being. The thingness of the phenomenological form of experience is assimilated and digested completely. All experience, all experience that is metabolized becomes the experiential field of luminous Being. Metabolized experience becomes a radiant trace within our embodied field of Luminous Being.

Whatever experience you have metabolized within the field of awareness becomes the Field of your Being. Experience of the "thing like" density of experience is digested and metabolized within the radiance of awareness. What remains is the experiential trace of the field of Being's metabolized experience of phenomenological form. The metabolized trace is located within and as the field of the luminous Being of awareness. The phenomena of the form is metabolized and transmuted into a radiant trace within the field of Being. The actuality of form becomes a felt sense of the radiant trace. The felt sense the radiant trace within the field of awareness is no longer an "object" or "state" self-contained and selforganizing our lived experience in actuality. This trace is not a cognitive, affective, imaginal experience of the memory of our mind body configuration. Traces are the luminously subtle radiant energetic qualities within the field of Being as the field. In the tantric Dzogchen text these luminous traces are described to be tiny spheres of vortices of light and energy. The traces are points of luminous energy.

\section{The Alaya - Vijnana As The Field of The Traces}

These radiant traces within the field of the Being of Awareness in the understanding of Existential Dzogchen is called the Alaya Vijnana Field. This field of person and personal experience exists life after life and death after death. In Dzogchen there is the ongoing continuity of Being that is infinite and forever unfolding. The Alaya-Vijnana field is the container 
of the radiant traces of existential life, life after life and death after death. This Alaya-Vijnana field is most important in our understanding of reincarnation and the ongoing continuity of personal Being. This understanding and knowledgeable Presentation of Dzogchen is completely freed from the early nihilistic non self-Buddhist's mechanistic teachings of Gautama. The Dzogchen understanding of the Alaya-Vijnana ontological field frees us from the Anatman assumptions of non self or selfless existence. Early Buddhism lacked an ontological basis of experience (Germano and Waldron, 2006).

Namkai Norbu the great contemporary Dzogchen Master would say over and over, Dzogchen does not belong to any religious tradition and neither does Dzogchen belong to any culture or country. Dzogchen is not simply a reflection of Transcendental Buddhism as some like to think.

The stabilized state of inner most awareness can metabolize traumatic experience and traumatic memory and traumatic somatic fixation. The true power of transitional space of primordial awareness is the power of metabolization and the transmutation of phenomenological experience into the vital luminous energy of the field of Being that we are.

By focusing and integrating our phenomenological experience within this realm of our awareness of awareness, and our remaining for a sustained time in this state, of awareness of awareness is the most powerful skillful method for our metabolization of experience. Through the metabolization of phenomenological experience, our metabolized radiant experience becomes the field of awareness which is the field of Being. Awareness transforms "experience" into vital energy and luminous knowing of Being. The field of transitional primordial awareness transforms human experience into energy, light, and embodied knowingness, the embodied vital field of Being. 
Traces of the emotional affective phenomenological experiential forms are no longer cognitive or affective states of mind but have become the field of radiant resonate energy. The "felt sense" remains as a radiant trace within the field of Being and as the field of Being. The fixedness of the phenomenological form disappears. The reification of the phenomenological form dissolves. The location of the phenomenological form dissolves from being located within our mind's embodiment. The concrete reification of the affective emotional form dissolves. The affective emotional form is initially within our psychological experience but outside of our field of inner most luminous awareness. The field of our inner most luminous awareness is our inner self as our embodied field of Being.

The field of luminous self-awareness integrates the emotional phenomenological experience into itself. The phenomenological forms of the affective sphere or affective state or ego state is assimilated and reformulated within the process of metabolization and transmutation within the field of luminous awareness. The reformulation of the experience of the phenomenological form takes place within the radiant power of the metabolization of luminous direct non conceptual awareness. The power of non-conceptual Gnosis metabolizes phenomenological memory and phenomenological experience.

Our mind body continuum without the embodiment of awareness, without the embodiment of the Being of awareness, without the embodiment of inner self, does not have the power of ontological metabolization. The field of Being as human awareness metabolizes dense and reified experience. Mind alone fragments under traumatic density. Our body alone fragments under traumatic somatic intensity. Where there is no embodied base of embodied Being of awareness and the embodied direct knowing of awareness knowing Being, there is only ontological emptiness and the absence of the innate presence of our 
Being. This absence of presence is an absence of our embodied self as the sense of our embodied Being. Without the base of Being, ontological metabolization does not take place. Without ontological metabolization, the subtle dimensions of our radiant field of Being will not become experientially apparent and translucent.

Awareness is a field of direct knowingness, a field of energy, a field of spaciousness, a field of light and a field of the direct self-illumination of phenomena and the self -knowing of the Being of phenomena. The field of radiant light is the metabolizer of experience. The metabolization of experience brings forth energy, vitalness and self-illumination of the embodied field of Being.

The metabolization of experience brings forth the metabolization of energy and corresponding embodiment of the radiance of the light of Being. In the metabolization of experience, energy, and vitality, the luminosity of awareness is increased in intensity and in depth and in the breath of range. In our metabolization of experience the deepening of the embodiment of luminous awareness takes place naturally. The field of Being infuses all experience and all experience is absorbed within the experience of the fluidity of our radiant Being.

\section{Existential Terror}

A foundational existential terror for a person is to become stuck in the catastrophic and primitive experience of unbearable absence of Being and the corresponding unbound desperate rage with the sense of there being no way out of infinite vacuum of emptiness. The person is terrified of touching and entering the primitive painful feelings of annihilation and the internal abyss like states of absence. Within the power of metabolization of our awareness field we can feel the existential support 
to enter these primitive states of void, and metabolize the experience of the abyss of Being. The power of awareness metabolizes the void, metabolizes the lack and the sense of infinite emptiness. As awareness metabolizes these states of absence, the field of Being self-manifests and the ongoing continuity of Being becomes completely possible in time. Our ongoing continuity of sense of self becomes embodied and the ontological anxiety of non being disappears. We may call this the experience of deathless awareness.

Within the field of awareness, we are able to integrate our states of mind and states of affective experience into this open luminous transitional space of awareness which is the field of Being as our own direct knowingness. In living within the field of awareness, a person is more capable to hold and metabolize experience and maintain boundaries as to what will happen within themselves. To integrate experience and assimilate experience into the field of awareness is to liberate our self through the metabolization of experience within the field of Being just as we are.

Within the base of awareness, a person begins to experience that the painful saturating states of experience can be directly touched, contained, assimilated and metabolized by the field of the embodied Being of awareness. The person is freer to experience everything and anything within their range of lived experience. Painful feelings and affective experience can be metabolized and digested in an unfolding step by step movement, of integrating everything into and within the field of awareness which is the field of Being. A person or religious tradition does not have to use dissociation and detachment as the only way of freeing oneself from painful states of experience and painful states of memory and painful states of non-Being. 


\section{Conclusion}

In the early Dzogchen Tantras of the 8th and 9th century CE there is a focus on the power of awareness illuminating the experience of Being and metabolizing reified states of mind, as well as metabolizing the generational field into the field of Being.

Without the sense of the base of the field of embodied awareness, the intense affective states of fear and terror as well as other forms of selfnegating experience can become completely saturating and consuming of our sense of embodied self. In saturated states of experience, intentional and even reflective capacity is often dissolved in the context of saturation, terror and annihilation anxiety. Saturated states consume our intentionality and our minds reflective capacity. The intentional function of the mind disappears in saturated states of overwhelming and intrusive painful experiences of agony.

The mind understands context and causal effect thinking. The mind becomes easily saturated by compelling painful experience. Our minds capacity for the metabolization of the complexity of dominating and traumatic experience, does not have the depth and breadth and the power of the embodied Beingness of our awareness field.

Moreover, Awareness metabolizes the subtle states of Being. Awareness metabolizes subtle states of energy. Awareness metabolizes the subtle energetic winds, and awareness metabolizes the subtle spheres of vortices of light of Non-Dualistic experience. Awareness metabolizes archetypal powers, and archetypal energies and archetypal spheres of light. Awareness metabolizes the density of light, and awareness metabolizes the subtle energies in to the liquidity of embodied Being. Our Awareness metabolizes the traces within the field and of the field of Being. 
Our embodiment of Being brings forth the experience of the indestructibleness of our ontological Being-ness. 


\section{References}

Bauer, R. (1976). A Gestalt Approach to Internal Objects. Psychotherapy, Research and Practice. Vol.13.

Bauer, R. (2019). The Absence of Self: An Existential Phenomenological View of the Anatman Experience. The Journal of Philosophical Investigations, Vol.13 (28).

Bauer, R. (2020). El uso del espacio transicional en psicoterapia con las preocupaciones existenciales de la experiencia borde rline. Revista Científica Arbitrada de la Fundación MenteClara, Vol.5 (133). doi: https://doi.org/10.32351/rca.v5.133

Bauer, R. (2020b). Igualitarismo humano y la ilusión patriarcal: Una visión fenomenológica. Revista Científica Arbitrada de la Fundación MenteClara, Vol.5 (122). doi: https://doi.org/10.32351/rca.v5.122

Baumer, B. (2011). Abinavagupta's Hermeneutics of the Absolute, India Institute of Advanced Study.

Capobianco, R. (2014). Heidegger's Way of Being, University of Toronto Pre ss.

Germano, D, and Waldron W. (2006). A Comparison of Alaya Vijnanain Yogacara and Dzogchen.In Buddhist Thought and Applied Psychological Research.Edited by D.K. Nauriyal, Michael Drumond and Y.B. Lal. Routledege,London and New York.

Lingpa, Dudjom. (2015). The Vajra Essence. Wisdom Publications. Translated by Allan Wallace.

Newman, John Henry (1903). “An Essay in The Grammar of Ascent.” Longmen and Green.

Rongzom Zangpo (1017). Entering the Way of the Great Vehicle, Shambhala Publications. Translated by Domine Sur.

Longchen Rabjam (2001). A Treasure Trove of Scriptural Transmiss ion, Padma Publishing. Translated by Richard Barron.

Daws, Loray. Editor (2016). On the Origin of the Self, The Collected Papers of Henry Elkin. EPIS Press.

Trigg, D. (2016). Anterior Origins: Merleau-Ponty and the Archaeology of the Body. Materialities of Passing: Explorations in Transformation, Transition and Transience, 239.

Winnicott, D. W. (1971). Playing and Reality. London: Routledge. 